DOI: $10.12775 /$ szhf.2013.007

DARIUSZ PAKALSKI

\title{
Hansa Castorpa sen o wielkości natury
}

Na początku niniejszego artykułu chciałbym przypomnieć dwie trywialne, ale moim zdaniem kluczowe, gdy idzie o zrozumienie fenomenu Czarodziejskiej góry Tomasza Manna tezy. Po pierwsze, powieść ta pozostaje pod wpływem filozofii Schopenhauera, po drugie, w filozofii Schopenhauera problematyka estetyczna odgrywa szczególną rolę. Mówi się tam wręcz o wyższości percepcji wartości estetycznych, nad refleksją intelektualną (przy kantowskim rozumieniu pojęcia „intelekt”).

Zawarta tu interpretacja zwraca się przeciwko powszechnie przyjętej manierze, ażeby Czarodziejska górę odczytywać jako przede wszystkim dialog „różnej maści intelektualistów”, dla którego to dialogu wszelkie opisy wartości estetycznych stanowią zaledwie tło. Często przy tym postrzega się fabułę powieści w sposób symbolistyczny, przypisując poglądom i postawom bohaterów określone postawy światopoglądowe powszechnie spotykane w czasach powstania dzieła. Nierzadko pada wówczas „dyżurne” pytanie: czy powieściowy Naptha był faktycznie odpowiednikiem Georga Lukácsa?

Tego typu pytania wydają się o tyle nieistotne, że z fabuły Czarodziejskiej góry jasno wynika, iż to nie dyskusje intelektualne stały się dla głównego bohatera powieści, Hansa Castorpa, bodźcem do swoistego przebudzenia duchowego. Ani zabiegi pedagogiczne Lodovica Settembriniego, ani (może tym bardziej) Leona Napthy, duchowego reakcjonisty, rzecznika anty-rozumu, jezuickiego mistyka, a przy tym komunisty, nie wywarły przecież na przemyślenia młodego bohatera istotnego wpływu. Więcej, poglądy tych dwu podstarzałych adwersarzy przedstawiane są często przez Manna tak, że ich 
prezentacje przypominają wynurzenia klaunów. Zwróćmy na przykład uwagę na następujący fragment:

Hans Castorp siedział z podbródkiem w pięści. Patrzał w górę ku mansardowemu oknu i w jego poczciwych niebieskich oczach malował się jakby upór. Milczał.

- Pan milczy - mówił Settembrini w podnieceniu. - Pan i jego kraj zachowujecie milczenie pełne zastrzeżeń co do przyszłości; milczenia tego nie można przejrzeć, więc też i osądzić jego głębi. Nie lubicie słowa; albo nim nie władacie, albo posługujecie się nim w jakiś nieprzyjazny sposób - świat słowa artykułowanego nie wie, co myślicie. Przyjacielu, to jest niebezpieczne. Mowa jest cywilizacją... Słowo, nawet najbardziej sprzeczne, jakże zobowiązuje... A milczenie czyni człowieka samotnym. Można przypuszczać, że swą samotność będzie pan usiłował przełamać czynami ${ }^{1}$.

Przeciętny niezmanierowany odbiorca tego typu pouczenia bez wątpienia potraktuje jako gadaninę nic nieroba i filistra, który będąc nawiedzony egzaltowanymi przeświadczeniami próbuje kogoś o czymś pouczyć, tworząc przy tym rzekome związki pomiędzy bardzo ogólnymi skojarzeniami.

W tym kontekście koniecznie trzeba zwrócić uwagę na fakt, że dwa tomy Czarodziejskiej góry, gdy idzie o równowagę litery i ducha, zdecydowanie różnią się od siebie. Mówiąc po prostu: tom drugi czyta się już z niejakim trudem. $\mathrm{W}$ tomie pierwszym opis procesu rozwoju gruźlicy połączony z wybuchem erotycznej pożądliwości Castorpa do pani Chauchat większość czytelników śledzi zapewne z fascynacją. Sygnalizowany wątek, bez wątpienia w tej części dzieła naczelny, kumuluje się w ostatnim rozdziale tego tomu zatytułowanym Noc Walpurgii: najpierw w słynnej scenie pożyczenia ołówka, a potem w dokładnym, gruntownym „iście niemieckim” wyznaniu miłosnym. W dalszych partiach dzieła wątek miłosny przygasa, a fabuła przepełnia się nudnymi i irytującymi kłótniami, spekulacjami o wyraźnym zabarwieniu ideologicznym, albo po prostu zwykłym gadulstwem, za którym czytelnik nadąża już $\mathrm{z}$ trudem, by nie powiedzieć z poczuciem niesmaku. Można odnieść wrażenie, że cała akcja drugiego tomu składa się na jakieś dopisane zakończenie, które, ku udręce odbiorcy, nie może niestety nastąpić.

Tu niejeden czytelnik być może zada sobie pytanie: czy nie byłoby lepiej, ażeby powieść skończyła się na pierwszym tomie, to znaczy na wielkim zna-

${ }^{1}$ T. Mann, Czarodziejska góra, tłum. J. Kramsztyk i J. Łukowski, Warszawa 1965, t. 2, s. $223-$ -224 . 
ku zapytania, pojawiającym się po scenie miłosnej pomiędzy Castorpem i Madame Chauchat?

Chciałbym powstrzymać się od spekulacji, na ile różnica fabuły obu tomów jest efektem celowego zabiegu Tomasza Manna, na ile zaś wynikiem przerwania na jakiś czas pracy nad powieścią i jej powtórnego wznowienia. Bez względu na przyczynę, faktem jest, że tom drugi zawiera krytyczną część dzieła dotyczącą (trzymajmy się tu dalej terminologii Schopenhauera) intelektualnego gadulstwa. Być może część ta w sposób zamierzony ma być nudna, przegadana, irytująca po to, by w nastrój nudy i irytacji wprowadzić również czytelnika. Czarodziejska góra nie jest przecież dziełem, które ma ot po prostu „podobać się". Jej przesłanie stanowi przede wszystkim przekaz pewnej prawdy dotyczącej człowieka i świata. Estetyka nie pełni tu roli przysłowiowego „kwiatka do kożucha”, ale staje się bezpośrednim sposobem przekazania wiedzy filozoficznej. A taka rolę przypisywał estetyce właśnie Schopenhauer.

Zastanówmy się więc: co stanowiło faktyczną przyczynę „przebudzenia duchowego" Castorpa? Pierwszą taką przyczyną był bez wątpienia zachwyt ciałem Kławdii Chauchat, do którego bohater zapłonął miłością - ciała niezbyt zdrowego, co biorąc pod uwagę rozmiar fascynacji, mogłoby napawać zdziwieniem.

Chciałbym postawić tezę interpretacyjną, że historia miłości Kławdii Chauchat i Hansa Castorpa jest w fabule Czarodziejskiej góry (a przynajmniej w jej pierwszej części) motywem kluczowym, czymś w rodzaju osi kompozycyjnej, wokół której rozgrywa się rozwlekła i pełna filozoficzno-politycznych dygresji akcja.

Pierwszy moment, w którym Castorp wkracza w sferę inności Madame Chauchat (jak można by to nazwać współcześnie, używając języka Levinasa) dostrzegamy we wspomnianej scenie z pożyczeniem ołówka. Sam akt pożyczenia nie jest tu tylko pretekstem do wkroczenia we właściwy wątek, który to pretekst, jako figura retoryczna w literaturoznawstwie polskim określany jest zaczerpniętą z Pana Tadeusza frazą „tabakierka księdza Robaka”. Nie chodzi tu też o wyrachowane działanie, kolokwialnie określane mianem „pretekstu do podrywu” na przykład w sensie: „podrywanie zacząłem od zapytania o godzinę". Motyw pożyczenia ołówka, nawiązujący do analogicznego przeżycia, które kiedyś w przeszłości stało się udziałem Castorpa i jego kolegi Przybysława Hippe, stanowił dla bohatera powieści naturalną i znaną mu sytuację, że w wyniku pewnego, na pozór błahego zdarzenia, bariera inności oddzielająca mnie od obcej osoby, zostaje przekroczona. 
Kolejnym ważnym krokiem owego przekraczania staje się otrzymanie przez Castorpa rentgenowskiego zdjęcia części układu kostnego uznanej za ideał kobiety. Co oznacza ten wątek, odważmy się to tak nazwać, nekrofilizmu?

Przytaczając jego interpretację, odwołam się do przykładu z oglądanego przeze mnie przed laty filmu. Jego bohater kocha piękną dziewczynę, której nie zna i tylko czasem ją spotyka. W efekcie uznaje ją za niedostępnego anioła. Potem zostają kolegami, przyjaciółmi, aż w końcu dochodzi do tego, że odprowadzając ją do domu może ją objąć i pocałować w policzek. A wtedy wykrzykuje zdumiony: ależ ty masz żebra! Brzmi to jak: ty jesteś człowiekiem, nie aniołem!

Madame Chauchat postrzegana dotychczas jako niedotykalny anioł, pokazując na zdjęciu fragment swego szkieletu, staje się na chwilę człowiekiem, po czym... wyjeżdża, czyli znika, a jej miejsce zastępują wyobrażenia. Fabułę związku miłosnego przenika odtąd pytanie: czy ci dwoje w końcu „dostaną się", a jeśli tak, to jak i jakie będą tego konsekwencje? Odpowiedź na pierwszą część owego pytania jest dość niejasna, ale twierdząca, odpowiedź na część drugą właściwie do końca pozostaje tajemnicą.

Tak czy inaczej Madame Chauchat pozostaje dla Castorpa wielkością, a ukorzenie się przed nią, związane z poczuciem własnej małości, staje się dla bohatera źródłem szczerej rozkoszy. Przypomnijmy scenę, gdy nie zważając na ostrzeżenia Settembriniego rozpaczającego na widok, że jego wychowanek „już się opuszcza na przednie kończyny, a niezadługo zacznie chrząkać”2, Castorp, tkwiąc na czworakach z nosem przy dywanie, coś bełkocze pani Chauchat o woni jej skóry pod kolanami. Ta woń, podobnie jak wcześniej zdjęcia fragmentu szkieletu, znów zdaje się przybliżać bohatera do cielesności ukochanej, której anielskość ukazała fragment swej ludzkiej strony.

Ów upadek Castorpa „na czworaka” w obliczu potęgi miłości przywodzi na myśl inny jego upadek, mający miejsce również w obliczu potęgi natury, ale jakże innej od ciepłej natury kobiecości. Chodzi mianowicie o upadek w śnieg, podczas samotnej wyprawy w góry.

W tym miejscu, pytając o motywy skłaniające Castorpa do wycieczki, która najpierw zdawała się romantyczna, a potem stała się awanturnicza i niebezpieczna, można wskazać na pragnienie analogiczne do wspomnianego powyżej: tak jak tam szczególne pożądanie bohatera budziło ciało kobiety (przy czym „ciało” należałoby rozumieć w pełnym sensie symbolizowanego

\footnotetext{
${ }^{2}$ Tamże, t. 1, s. 319.
} 
przez owo słowo fenomenu natury), tak tutaj bierze go we władzę pragnienie wejścia w ściślejszy i swobodniejszy (a więc znów bezpośredni) „kontakt ze śnieżną pustynią gór”3.

Za znikającym w śnieżnej kurzawie bohaterem znowu słyszymy głos Settembriniego: „Inżynierze! Co pan robi!”. W tym wypadku nie jest nawet pewne, czy Settembrini naprawdę wołał, czy Castorpowi tak się tylko zdawało. Istotne jest, że dla rzekomo odkrywczego i w jakimś sensie buntowniczego, a faktycznie bardzo układnego Settembriniego tak „wspinaczka na naturę kobiecości”, jak i wyprawa ku górskim szczytom, oznacza konieczność opuszczenia ciepłego świata kultury, który należy tylko „rewolucyjnie układać”, i nie w głowie mu podjęcie awanturniczej wyprawy ku wysokościom, z których wyobraźnia może jedynie spaść - najpierw na cztery nogi, a potem już w ogóle. $Z$ całą pewnością poglądy filozofa kultury, jakim był Naptha, byłyby w tym miejscu podobne, choć nie jest wykluczone, że chociażby z przekory wobec Settembriniego jako swego adwersarza wyraziłby je inaczej twierdząc, że rzekomo są jednak inne.

Przypomnijmy jak zaczyna się owa w ostatecznym rozrachunku karkołomna wyprawa stanowiąca swoisty rewers „wyprawy do ciała Madame Chauchat". Na początku bohatera przenika silne przeżycie estetyczne, które może się kojarzyć $\mathrm{z}$ poczuciem piękna, lecz $\mathrm{w}$ istocie trudno je powiązać z jakąś konkretną, czy może raczej szczegółową wartością. Wspinając się po stoku, bohater od czasu do czasu zatrzymuje się, ażeby przez nabrany do talerzyka swego narciarskiego kijka śnieg popatrzeć na niebo. Przez warstwę śniegu pada delikatne światło, "górskie i głębinowe”, „jak lód przejrzyste, a zarazem cieniste i tajemniczo pociągające". Zwróćmy uwagę: owo światło przypomina mu niebieskoszarą barwę oczu, które, jak mu się wydaje, zawsze nosiły dla niego odcień i głębię dalekich gór.

Zachwyt ową estetyczną doskonałością natury, nie dającą się w tym momencie określić poprzez użycie nazwy jakiejkolwiek konkretnej wartości, nawet piękna, przy spotkaniu z fenomenem kobiecości nieuchronnie prowadzi do upadku "na czworaka”. Kobieta staje się Kirke zmieniającą swego mężczyznę w czworonożne zwierzę. Ale zwierzęcość nie oznacza w tym wypadku wyzbycia się wyższych wartości. Ów mężczyzna zniża się do poziomu czterech kończyn sam, czując się wobec wyśnionej wielkości natury kobiecej mały. Jest więc towarzyszem Odyseusza, który sam siebie zamienia w świnię,

\footnotetext{
${ }^{3}$ Tamże, t. 2, s. 166.
} 
choć być może otoczeniu (a więc Odyseuszowi, którego rolę gra tu Settembrini) może się wydawać, że czyni to złośliwa boginka ${ }^{4}$.

Konsekwencje upadku "na czworaka” w obliczu zimnej potęgi natury, a nie ciepłej natury kobiecości okazują się niebezpieczne już nie dla faktu przynależności Castorpa do kultury, lecz wprost dla jego życia. Fascynujące światło przenikające przez śnieg podczas górskiej wyprawy, podobnie jak wcześniej „fascynujące światło” doskonałości kobiecej natury obserwowanej przez zadurzonego mężczyznę, w pewnym momencie zostaje zastąpione przez złowrogą, niszczącą potęgę. Łatwo można sobie wyobrazić, że przysypywany śniegiem Castorp, zniżony już do poziomu „czterech kończyn”, najpierw zostaje w ogóle powalony na ziemię, potem zaś w nią „wdeptany”. Ale bohaterowi los taki nie jest pisany. Ratuje go poczucie dystansu w stosunku do potęgi, w obliczu której nagle się znalazł. Będąc bohaterem rozgrywającego się dramatu, tak w przypadku aktu dotyczącego zderzenia $\mathrm{z}$ naturą kobiecą, jak i konfrontacji z martwą naturą gór, zdaje sobie sprawę, że w dramacie tym to właśnie on dokonał „odsłonięcia kurtyny”.

Przy konfrontacji z najpierw fascynującą, a potem powalającą naturą kobiety, która ostatecznie nie zdołała go zniszczyć, owym odsłonięciem były słowa: „Czy ty przypadkiem nie masz ołówka?” Gdyby słowa te nie zostały wypowiedziane, być może nie zniżyłby się później do poziomu czterech kończyn przed przybierającą pozę Kirke Madame Chauchat. Podobnie, gdyby nie zdecydował się pójść w góry, nigdy nie zagroziłby mu upadek w symbolizujący potęgę natury nieożywiony śnieg. Pozostałby kimś podobnym do Settembriniego, kto przepełniony lękiem wobec żywiołu natury zamyka się w ciasnym kręgu wyznaczonej przez kulturę układności i potrafi tylko „gadać i chodzić” albo „chodzić i gadać”, obserwując zaś przygody podobne do tych, które przypadły mu w faktycznej akcji powieści, jemu samemu potrafi tylko wymówić ze zgrozą swoje: „Inżynierze! Co pan robi!” Manieryzm pozy Settembriniego, bo przecież Castorp nie był żadnym inżynierem, nie został w tym miejscu przez Manna podkreślony przypadkowo. Settembrini, „wielki luminarz", naprawdę panicznie boi się uczynić choćby jeden mały krok

\footnotetext{
${ }^{4} \mathrm{~W}$ tym kontekście warto przypomnieć powieść Liona Feuchtwangera Odyseusz i wieprze. Znany epizod z Odysei zostaje tu zinterpretowany w niezwykle oryginalny sposób: otóż towarzysze Odyseusza zamienieni w wieprze wcale nie chcą, ażeby zdjęto z nich czar i przywrócono ich do ludzkiej postaci. Bycie wieprzami i chodzenie na czworakach przed piękną boginką bardzo im odpowiada.
} 
w stronę świata, który naprawdę się dzieje, a nie został tylko wygadany ${ }^{5}$. Rzekomo buntowniczy Naphta przejawia zresztą podobną postawę.

Dla Castorpa wyprawa w góry nie oznacza oczywiście, że po fazie powalenia „na cztery kończyny” czeka go faza wdeptania w ziemię. Nie tylko bowiem odsłonił on kurtynę swego dramatu, ale jest również w możności opuszczenia jej. Dokonuje tego, wypowiadając sobie słynną frazę: „Milcz i staraj się ujść cało" 6 stanowiącą swoisty rewers: „Czy ty przypadkiem nie masz ołówka?”

Mann odwołuje się tu do znanego doświadczenia, że podobno zamarzaniu w czasie zamieci towarzyszy poczucie senności i błogostanu, któremu, znalazłszy się w obliczu tego typu niebezpieczeństwa, nie wolno ulegać. Można więc zaryzykować tezę interpretacyjną, że Castorp wrócił ze swej wyprawy w góry żywy dlatego, bo był nie tylko uczestnikiem, ale i obserwatorem sprowokowanego przez siebie dramatu i że ostatecznie to rola obserwatora okazała się dla niego decydująca.

Podobnie wcześniejszy upadek w naturę kobiecą mógłby się dla niego zakończyć katastrofą analogiczną do tej, jaka spotkała starego profesora, bohatera filmu Błękitny anioł, powstałego na postawie prozy Henryka Manna, brata Tomasza. Ów profesor nie potrafił opuścić kurtyny dramatu, którą wcześniej podniósł. Znaczy to, że nie był w stanie wypowiedzieć sakramentalnej formuły „milcz i staraj się ujść cało”, równie skutecznej w obliczu tych zagrożeń, które niesie ze sobą dzika natura gór, jak i tych, które wyłaniają się spoza zniewalającej natury kobiecej.

Czarodziejska góra jest niewątpliwie dziełem filozoficznym. W jakim sensie utwór literacki posiadający fabułę, w której występują fikcyjni bohaterowie, może zasługiwać na takie miano?

W niemieckim języku filozoficznym czasami używa się zwrotu Bewußtsein überhaupt, charakterystycznego zwłaszcza dla Jaspersowskiej interpretacji Kanta. Gdyby go dokładnie przetłumaczyć, brzmiałby on „świadomość jako to, co uogólnione”. Oznacza on takie poznanie psychiki, które odnosi się do jej cech przysługujących wszelkiej psychice w ogóle. Zdaniem Kanta język nauki ścisłej, której nie oddzielał on jeszcze od filozofii, dotyczyć miał

\footnotetext{
${ }^{5}$ Warto zaznaczyć, że gadanina była dla Martina Heideggera jednym z podstawowych przejawów upadku w „się”.

${ }^{6}$ T. Mann, dz. cyt., t. 2, s. 181.
} 
właśnie „pojęciowej wiedzy o tym, co uogólnione”. Tak pojmowanej filozofii jako nauce przeciwstawiał on wiedzę o człowieku, którą nazywał antropologią w ujęciu pragmatycznym, bo w dużej części opierała się ona tylko na obserwacji. Wiedza ta miała zastąpić dotychczasową psychologię racjonalną, stanowiącą po części psychologię racjonalno-empiryczną, a po części to, co dziś nazywamy antropologią w najszerszym tego słowa rozumieniu, czyli antropologię biologiczną, kulturową, filozoficzną, itp.

W XIX wieku na dużą skalę zaczyna się rozwijać sposób filozofowania znany już od starożytności, a powszechnie określany mianem prozy filozoficznej. Proza taka nie jest logicznym zapisem przekazywanych treści, ale symbolem hermeneutycznym, który ma przywieść czytelnika do stanu podobnego do tego, jaki odczuwał autor. Dilthey, wyjaśniając istotę takiego symbolu, wprowadził rozróżnienie pomiędzy wyjaśnieniem komuś czegoś, czyli wiedzą przekazywaną dyskursywnie (świadomość w ogóle), a zrozumieniem, oznaczającym współrozumienie z kimś, co Heidegger określi później współbyciem-oto (Mitdasein).

Czarodziejska góra jako dzieło filozoficzne jest niewątpliwie jednym wielkim zbiorem i ciągiem symboli hermeneutycznych. Opisując narrację dzieła literackiego w języku filozofii logicznej, rekonstruujemy tylko jego anatomię, oczekując, że samo oddziaływanie owego dzieła, jako żywej struktury organicznej, czytelnik będzie musiał odtworzyć sobie w swej wyobraźni sam.

Jakie filozoficzne znaczenie mają dwa przywołane tu epizody z powieści? Zanim przejdziemy do rekonstrukcji niektórych wątków tej filozofii, która, mimo że jest autentycznym dziełem Tomasza Manna, daje się porównać z teoriami innych filozofów, zajmijmy się pokrótce kluczowym dla myśli wywodzącej się od Schopenhauera motywem snu.

Nie idzie tu oczywiście o sen w sensie dosłownym, bo Castorp nie zasnął przecież ani na widok ciała Madame Chauchat, ani podczas śnieżnej burzy. Chodzi o to, że w jednym i w drugimi wypadku bohater pogrążył się w stan upojenia (wino wypite podczas zamieci śnieżnej jest tu ważnym symbolem), tworząc ze świata naturalnego dzieło sztuki, w którym on sam był głównym aktorem.

Spektakl taki przywodzi nam na myśl motyw upojenia dionizyjskiego, znany z Narodzin tragedii Nietzschego, a nawiązujący swą treścią do filozofii Schopenhauera. Jak przypomina Mirosław Żelazny, w filozofii europejskiej postrzeżenia empiryczne wielokrotnie porównywano do marzenia sennego ${ }^{7}$.

${ }^{7}$ M. Żelazny, Nietzsche, „ten wielki wzgardziciel”, Toruń 2007, s. 15. 
Czynił to Platon, św. Augustyn, Kartezjusz i wielu innych. Nietzsche, pisząc o twórczości artystycznej kreującej rzeczywistość, o której nawet w akcie katharsis wiemy, że nie jest rzeczywistością naturalną czy potoczną, używa terminu „pozór pozoru”.

Odwróćmy się na chwilę od swej własnej „rzeczywistości”, pomyślmy sobie swe istnienie empirycznie i istnienie świata w ogóle, jako każdej chwili wytwarzane wyobrażenie pra-jedni (des Ur-Einen), to będziemy musieli uważać teraz sen jako pozór pozoru, zatem za jeszcze wyższe zadowolenie prażądzy pozorů

Żelazny w tego rodzaju filozofii artystycznego pozoru doszukuje się inspiracji Schopenhauerowskich:

W systemie Schopenhauera za „pozór pozoru” należałoby uznać nie tylko działalność artystyczną, ale wszelkie próby systematyzacji postrzeżeń empirycznych w formie jakiegokolwiek logosu. Pozorem pozoru byłaby nauka, religia, etyka, idea państwowości, jednym słowem wszelka ludzka działalność, usiłująca zbudować ponad płaszczyzną czystej empiryczności kolejną sztuczną płaszczyznę porządku. Dla twórcy metafizyki woli, wszystkie rodzaje aktywności zewnętrznej muszą się obracać w kręgu jednostkowych obiektywizacji, co nieuchronnie skazuje ich kreatora na samotność i cierpienie. Wyjątek stanowiła twórczość artystyczna. Poczucie piękna wiąże Schopenhauer z poczuciem bezinteresowności, a sztukę z dążeniem do wyrwania się z zaklętego kręgu obiektywizacji i sięgnięciem ku rzeczywistej istocie świata. Tendencję tę dostrzega nawet w najniższym rodzaju sztuki, w architekturze 9 .

Filozofia Manna była niewątpliwie silniej inspirowana przez źródłowe poglądy Schopenhauera, aniżeli przez ich metamorfozę zawartą w Narodzinach tragedii Nietzschego. Schopenhauer zaś zarówno pojęcie snu, jak i upojenia odnosi nie tylko do tego, co Nietzsche określa mianem mitu dionizyjskiego, ale również do tego, co zwie mitem apollińskim. A sen, który przeżywa Castorp, zarówno fascynując się ciałem madame Chauchat, jak i egzaltując się burzą śnieżną, jest niewątpliwie snem apollińskim.

W obu wypadkach owo wejście ze świata rzeczywistości w świat snu odbywa się w sposób symboliczny, przypominając przejście Alicji na drugą stronę lustra. W przypadku pierwszym owo przejście dokonuje się w akcie pożycze-

${ }^{8}$ F. Nietzsche, Narodziny tragedii $z$ ducha muzyki, tłum. L. Staff, Warszawa 1907, s. 22.

${ }^{9}$ M. Żelazny, dz. cyt., s. 15. 
nia ołówka. Symbolika tego aktu daje się zinterpretować dość łatwo. Obok Castorpa znajduje się ktoś, kto jest ową anonimową, Jaspersowską „świadomością w ogóle". Dając mi swój ołówek, ów ktoś tworzy natomiast ze mną pewne współbycie oto, bo poniekąd daje mi część samego siebie. To ofiarowanie samego siebie oznacza również ofiarowanie mi kawałka swej cielesności, co niekoniecznie musi oznaczać jeszcze relację erotyczną, choć w przypadku stosunku Castorpa do Kławdii Chauchat to właśnie się zdarza.

Mann prezentuje więc tu niezwykle interesującą koncepcję mechanizmu zakochiwania się. Madame Chauchat, ofiarowując Castorpowi część własnego ciała w postaci ołówka, w jakiś sposób „otwiera się na niego”. Kolejny etap otwierania to doświadczenie słabości jej ciała, toczonego przez chorobę i śmiertelnego, co ewidentnie potwierdza zdjęcie rentgenowskie. Wraz z tym doświadczeniem kobieta otwiera się na Castorpa po raz drugi, pokazując, jaka jest słaba, a więc przystępna i potrzebująca. Ale Madame Chauchat jako „kobieta z krwi i kości” prędko opuszcza świat snu Castorpa uświadamiając $\mathrm{mu}$, że ani nie kocha bohatera, ani go nie potrzebuje. Ujmując ściślej: takie sygnały nadaje $\mathrm{w}$ ogólności, czasami powracając w ów świat snu w aktach kokieterii. Castorp pozostaje zaś w swym świecie snu z wyśnioną ukochaną, a fakt, że ta wyjeżdża i może już żyć tylko w jego marzeniach, jedynie go w tym śnie utwierdza.

Mann wyraźnie daje do zrozumienia, że wyśniona przez Castorpa Madame Chauchat ma się nijak do realnej kobiety noszącej to nazwisko. Kobietę tę czytelnik widzi oczyma zewnętrznego obserwatora, bo egzaltacje Castorpa może on jedynie przyjąć do świadomości. A jak jest owa Madame Chauchat widziana z pozycji świata jawy?

Nie wydaje się ona atrakcyjna ani fizycznie, ani duchowo. Jej ciało jest chore, a motyw zdjęcia rentgenowskiego wprawiającego Castorpa w egzaltację, niejednego czytelnika mógłby wprawić w odrazę. Gdy idzie o walory duchowe, bohaterka jawi się jako zmanierowana kokietka, igrająca z uczuciami kochającego ją mężczyzny, wdająca się natomiast w związki z innymi mężczyznami, mało atrakcyjnymi duchowo, za to majętnymi i wpływowymi. Używając zwrotu Sartrea, można byłoby powiedzieć, że prawdziwa Madame Chauchat stanowiła tylko symbol, pod wpływem którego w wyobraźni Castorpa doszło do powstania wizji ukochanej kobiety, będącej „nadzwyczajnym skumulowaniem gęstości świata”. Madame Chauchat stała się ideałem, ale takim, który zawierał moment słabości umożliwiający Castorpowi dostęp do siebie.

Bohaterami takiego snu o wielkiej osobie, która jest wielka tylko w oczach kogoś kto śni, mogą się stawać, na mocy szczególnego momentu estetyczne- 
go przeżycia, takiego jak wspomniane pożyczenie ołówka lub zdjęcie rentgenowskie, a także na przykład szczególny ubiór czy postawa, osoby określane jako zupełnie nieciekawe, nawet zbrodniarze. Zjawisko to świetnie opisał Jerzy Kosiński:

Oficer podszedł do mnie nonszalanckim krokiem, uderzając miarowo trzcinką w szew świeżo wyprasowanych spodni. Odkąd ukazał się na dziedzińcu, nie potrafiłem oderwać od niego wzroku. Było w nim coś absolutnie nadludzkiego. Zgrabna sylwetka odcinała się trwałą czernią od szarego, nijakiego tła. W świecie ludzi o udręczonych obliczach, $\mathrm{z}$ wybitymi oczami, o krwawych, posiniaczonych lub powykręcanych kończynach, wśród cuchnących, połamanych ciał, jakich widziałem już tyle, stanowił okaz schludnej doskonałości, której nic nie mogło pokalać; wpatrywałem się z zachwytem w gładką, woskowatą twarz, jasnozłote włosy wystające spod wysokiej czapki, oczy z czystego metalu. Każdy ruch zdawał się świadczyć, że ciało oficera napędza jakaś ogromna wewnętrzna siła. Granitowe brzmienie jego mowy pasowało idealnie do rozkazów zlecających zabijanie nędznych, gorszych istot. Podziwiając lśniącą trupią główkę i skrzyżowane piszczele zdobiące czapkę, poczułem ukłucie zawiści, jakiej nie znałem nigdy dotąd. Pomyślałem, jakby to dobrze było mieć taki lśniący, łysy czerep zamiast mojej cygańskiej twarzy, nie lubianej i napawającej lękiem tylu prawych ludzi.

Oficer przyglądał mi się badawczo. Czułem się jak rozdeptana glista, z której wnętrzności wyciekają w kurz, stworzenie nie mogące nikogo skrzywdzić, choć w każdym wzbudzające niechęć i wstręt. W obliczu tak wspaniałej istoty jak oficer, uzbrojony we wszystkie oznaki potęgi i majestatu, szczerze wstydziłem się swojego wyglądu. Nie miałem nic przeciwko temu, żeby Niemiec mnie zabił. Wpatrzony w ozdobną klamrę szerokiego pasa znajdującą się dokładnie na poziomie moich oczu, czekałem na mądrą decyzję jej właściciela.

Na dziedzińcu znów zaległa cisza. Żołnierze stali posłusznie, gotowi na dalsze rozkazy. Wiedziałem, że właśnie waży się mój los, ale była to dla mnie rzecz całkowicie obojętna. Wierzyłem bezgranicznie w słuszność decyzji podjętej przez tego człowieka. Wiedziałem, że posiada przymioty obce zwykłym śmiertelnikom.

Zadźwięczała krótka komenda. Oficer odmaszerował. Żołnierz pchnął mnie brutalnie w stronę bramy. Żałując, że to wspaniałe spotkanie zakończyło się tak szybko, wyszedłem wolno przez bramę i wpadłem prosto w pulchne ramiona księdza, który czekał na zewnątrz. Wyglądał jeszcze żałośniej, niż pamiętałem. $\mathrm{W}$ porównaniu z mundurem ozdobionym trupią główką, piszczelami i błyskawicami, jego sutanna była zniszczoną szmatą ${ }^{10}$.

${ }^{10}$ J. Kosiński, Malowany ptak, tłum. T. Mirkowicz, Warszawa 1992, s. 112-113. 
Żelazny komentuje powyższy fragment następująco:

Opisana postawa chłopca z całą pewnością dałaby się określić jako nieszczęsna. Ksiądz, który narażając życie uratował go od śmierci, przysłowiowy sprawiedliwy wśród narodów świata, jawi mu się jako postać żałosna. Ma do niego pretensje, że przeszkodził, by wspaniały i wzniosły esesman go zabił. Patrzy więc na świat z punktu Savaryego, ale jakże karykaturalne cechy przejawia widziana stąd wielkość! Czy bowiem ów niemiecki oficer, z całą pewnością jakiś prymitywny typ w eleganckim mundurze, wykształceniem i mądrością na pewno nie dorównujący żałośnie wyglądającemu księdzu, może być przez normalnego człowieka utożsamiony z „okiem Opatrzności”? ${ }^{11}$

Warto zwrócić uwagę, że akcję Malowanego ptaka, książki, której fabuła daleko odbiega od jakiejkolwiek prawdopodobnej historii, często określa się jako przebiegającą $\mathrm{w}$ świecie snu. Porównajmy wyśnionego przez młodego żydowskiego chłopca esesmana z wyśnioną przez Castorpa Madame Chauchat.

Wielkość wyśnionej przez Castorpa kobiety jest wielkością anioła, wielkość wyśnionego przez żydowskiego chłopca esesmana wielkością diabła. Obydwie mają się nijak do realnych postaci kobiety i mężczyzny, które stały się przyczyną ich zaistnienia. Ale obydwie, gdy pojawiają się w świecie snu, sprawiają oglądającemu je widzowi rozkosz, wynikającą już z faktu, że ma on „szczęście” w jakiejkolwiek formie obcować z kimś tak wielkim. Taką rozkosz spowodowaną własną małością, w estetyce określa się mianem wzniosłości.

Immanuel Kant, analizując zjawisko wzniosłości w Krytyce władzy sądzenia zauważa, że jest to zjawisko estetyczne, a więc w czystej postaci pozbawione podstaw do wartościowania wedle kryteriów dobra i zła. Wielka pani Chauchat jest aniołem tylko mocą doczepionego do jej wielkości wyobrażenia dobra (nie jest zresztą jednoznaczne, czy właśnie o dobro w tym wypadku chodzi), natomiast wielki esesman jest diabłem mocą doczepionej do jego, wyśnionej przez biednego chłopca wielkości idei zła (czytelnikowi zło wyrządzane przez tego prymitywnego typa zdecydowanie skojarzy się z jego małością). Dlatego Kant, który chce zanalizować wzniosłość jako czyste zjawisko estetyczne nie analizuje go na przykładzie wielkości ludzkiej osoby, bo tu wartość estetyczna łączy się z wartościami pozaestetycznymi. Z podobnych przyczyn nie analizuje go na przykładzie organizmów przyrody ożywionej ani dzieł sztuki, bo tu również wielkość estetyczna zawsze wiąże się z innymi

${ }^{11}$ M. Żelazny, Filozofia i psychologia egzystencjalna, Toruń 2010, s. 463. 
rodzajami celowości. Czystej wielkości estetycznej, postuluje, należy doszukiwać się w surowych zjawiskach przyrody ${ }^{12}$.

Gdy idzie o ten rodzaj zjawisk postuluje rozróżnienie dwóch klas ich wielkości. Pierwsza z nich, to wielkość matematyczna polegająca na pełnej rozkoszy kontemplacji takiego zjawiska, jak na przykład wielkość piramidy czy górskiego szczytu. Druga to wielkość dynamiczna odczuwana podczas kontaktu z siłą takiego fenomenu jak rozszalałe morze, wybuch wulkanu, albo, tak jak w Czarodziejskiej górze - burzy śnieżnej.

Kontakt Castorpa $\mathrm{z}$ burzą rzeczywiście ma charakter kontaktu ze zjawiskiem czysto estetycznym. Inaczej niż przy kontakcie z ciałem pani Chauchat, sąd estetyczny nie jest tu powiązany z żadną formą władzy pożądania, ani $\mathrm{z}$ żadnym innym odczuciem wartości.

Ale Mann nie popełnia pewnego błędu, który wkradł się do koncepcji Kanta. Ten ostatni twierdził mianowicie, że ktoś, kto się lęka wielkości obserwowanego zjawiska, nie jest w stanie wydać sądu o jego wielkości ${ }^{13}$. Takie ujęcie może by się jeszcze nawet zgadzało z koncepcją Manna, ale Kant idzie dalej, twierdząc, że po to, ażeby móc na przykład rozkoszować się wielkością burzy na morzu burzę tę trzeba obserwować z bezpiecznego miejsca na brzegu. Tego typu uczucie rozkoszy nie może więc na przykład stać się udziałem rozbitka znajdującego się w miotanej przez fale szalupie.

Przygoda Castorpa pokazuje, że warunek ten wcale nie jest konieczny. Mann w swych spostrzeżeniach bliższy jest w tym miejscu koncepcji Schopenhauera aniżeli Kanta. Zagubienie w śnieżnej burzy, połączone z możliwością zatracenia się w niej, faktycznie przywodzi w tym miejscu na myśl Schopenhauerowską koncepcję nirwany, jako radości z samozatraty i roztopienia się we wszechogarniającej sile.

Odwołując się do dwu bardzo ważnych scen z Czarodziejskiej góry, starałem się wykazać, w jakim sensie dzieło to zawiera konkretną wykładnię poglądów filozoficznych. Rekonstrukcja procesu wyśnienia przez bohatera doskonałej wielkości w obu przypadkach została tu przez Manna dokonana bardzo precyzyjnie. Ale pisarzowi chodzi nie tylko o wyjaśnienie istoty zjawiska wielkości dokonane w taki sposób, jak czynił to Kant czy Schopenhauer.

\footnotetext{
${ }^{12}$ I. Kant, Krytyka władzy sądzenia, tłum. J. Gałecki, Warszawa 1964, s. 144.

${ }^{13}$ Tamże, s. 150.
} 
Proza Czarodziejskiej góry jest w stanie wprawić w stan podobny do iluzji snu również czytelnika, czego nie może sprawić suchy język filozoficzny, dostarczający tylko opisu i wyjaśnienia.

\section{Abstract \\ Hans Castorp Dream about the Greatness of Nature}

Keywords: aesthetics, the sublime, dream, nature spiritual metamorphosis

In the article two key chapters of Thomas Mann's "The Magic Mountain", namely "Walpurgis Night" and "Snow" are interpreted in the categories of aesthetic experience. In both of them Hans Castorp is lead into a dream, which could be treated as a hermeneutical symbol. Castorp experiences the feeling of the sublime which is a source of the spiritual metamorphosis. Seen from this angle Castorp turns out to be a literary expression of a new anthropological conception of man, and "The Magic Mountain" - a critique of the attempts to realize such a conception by the help of a solely intellectual argumentation. 